As a background to satisfying this increasingly urgent need, the planned World Decade of The Biosphere is intended, and seems destined, ${ }^{+}$to inform and educate people throughout the world about The Biosphere and how we humans are all (1) an integral part of it, (2) utterly dependent on it, and yet (3) threatening it by our pressures of numbers and actions. Such world-wide education concerning our planetary life-support is surely a necessary basis for public understanding and due support inter alia of such important developments as the work of SCOPE* the World Conservation Strategy, the Man and the Biosphere Programme, and much of the work of UNEP $\ddagger$ which we are featuring in our present issue.

Despite claims that may be made by governments, politicians, academics, and yet other leaders, the private sector of business enterprise probably has at its disposal far more human talent, or at least the wherewithal to attract and use it, than any other faction in the entire world. From discussions with some businessmen who understand the concept of Our Biosphere, we are confident that their support for the movement to save it will be forthcoming at least when Man's dependence on it is fully realized; herein lies much of our hope, such as indeed 'springs eternal in the human breast'.

What is needed is a change from the popular image of a negative, non-dividend-paying Biosphere to a positive, sine qua non one (without which modern civilizations could not long survive, hope would be groundless, business could not function, and all enterprise would be pointless). Our plans for the Decade are mainly of an educational nature, of which the following 'round dozen' include some that should be eminently capable of enterprising promotion-often on the sine qua non basis:

1) Publishing and Broadcasting Support by Every Appropriate Means.

2) Other Vehicles of Desirable Publicity, including Campaigns of Posters and Stickers.

3) Instructive Advertising and Audience-attracting Showmanship.

4) Books on The Biosphere and Illustrated Study Manuals.

5) Specialist Research and Application.

6) Need to Control Human Numbers and Behaviour.

7) National Parks, Biosphere Reserves, and Biological Gardens etc.

8) Conferences, Meetings, and other 'free' Deliberations.

9) Need to Change Human Attitudes.

10) Need to Establish Due Ethics and Laws.

11) Institutional and Organizational Involvement towards Survival.

12) 'Guardians of The Biosphere' Recognition and Awards.

Could not worthy NGOs* or private enterprise take care of some of these needs before it is too late, and meanwhile add others - such as anti-pollution measures, massive revegetation, and collection and recycling of wastes? Further possibilities that spring to mind include 'ethical' firms to replace ones that are closed down for environmental reasons or are rendered unprofitable through environmentalists' actions or satisfaction of their demands; also firms of consultants, teams of monitors, and groups of specialists in environmental management and law.

One can envisage more and more profitable concerns springing up and flourishing in these fields of endeavour-to the lasting benefit of our vulnerable Biosphere, while other aspects of its needed stability are taken care of by good government. Only through sound actions in these vital respects can we aspire to have protractedly sustainable societies - such as are unthinkable without due care for the health of The Biosphere in which they all subsist. Accordingly we plan in our next issue to feature the above-mentioned World Decade of The Biosphere in the prominent manner which it surely deserves.

N.P.

\footnotetext{
†Thus, for example, even before its launching (probably with a 2-pages' Declaration on Environment Day [June 5th] this year), the project has been strongly endorsed by world bodies, while two particularly pertinent organizations in North America, namely the National Science Teachers Association and the National Association for Environmental Education have, without prompting from us but to our great gratification, set up special committees to support the Decade, and, in the latter case, is contemplating making it the main theme of their next international conference (in Canada in 1984).

*SCOPE = Scientific Committee On Problems of the Environment of the International Council of Scientific Unions, which in several respects is the world's scientific 'Summit'.

\$UNEP = United Nations Environment Programme.

*NGOs = Non-Governmental Organizations, or, as we prefer to call the international ones nowadays, 'INGOs'.
}

\title{
Towards a Universal Declaration of Respect for Nature and The Biosphere
}

Dean Arthur H. Westing's paper 'A World in Balance', published in last Autumn's issue of Environmental Conservation, provides very interesting reading and leads up, in a most convincing way, to an expression of the need for a 'Universal Declaration of Respect for Nature'. It is high time indeed that some order be put into the minds of those people who profess to care about 'Ecology', many of whom fail to see their own involvement and are content to lay the blame on powerful anonymous bodies. One would like to see 'Ecology' taken out of politics and turned into what could amount to a faith, but under proper scientific leadership.

Dr Westing distinguishes three types of countries: the rich, numbering 27 , followed by 43 nations of average wealth and finally by the poor nations. Of these last there must be more than 80 . May I be allowed to add a footnote to his figures for the benefit of those readers in rich countries who might feel an undue sense of guilt, and of those in poor countries who might be hasty in apportioning the blame for our world's present predicament? 
and of those in poor countries who might be hasty in apportioning the blame for our world's present predicament?

If you leave out of account the oil-producing countries of the Third World, whose economies are subject to unusual circumstances, you find that all the rich countries are situated, at least in part, either between latitude $40^{\circ} \mathrm{N}$ and the Arctic Circle or else to the south of $20^{\circ} \mathrm{S}$, the less prosperous in the former zone being either members of the Comecon or those Mediterranean countries which Churchill once referred to as Europe's 'soft underbelly'.

In general, countries enjoying 'average wealth' are situated between latitude $40^{\circ} \mathrm{N}$ or $20^{\circ} \mathrm{S}$ and the tropics, while all but 10 of the poor countries lie in the Equatorial zone, between the Tropic of Cancer and The Tropic of Capricorn.

We owe it substantially to relatively recent history that we may no longer refer to racial differences. From their negation, it is only one step further to assert that all men are born with equal possibilities and equal needs. While the first of these assertions may be thought arguable, the second clearly is nonsense. I was once told of the astounding amount of steak needed in winter to keep up the strength of a lumberjack working in the Canadian forest. The figure was, if I remember correctly, in excess of one kilogram a day. If a northern European were asked to go through a winter on what is ample food for a fellah in the upper Nile Valley, he would most probably die; and so he would if clad or housed like a fellah.

The fact is that the rich are rich partly out of habituation; what seems essential to them is a luxury quite beyond the dreams of the average inhabitant of the poor countries. Accordingly it is unavoidable that those living in cold climates should make relatively great demands on world energy resources, though this clearly involves for them certain duties.

The first of these duties is not to proliferate unduly: this they seem to fulfil. The second duty is to exercise much greater care than at present in the way they satisfy their needs, the aim being to avoid doing so at the expense of the poor nations. Finally, they should give the benefit of the ingenuity gained through having to survive in difficult climates, to helping the poor nations to fulfil their obligations to The Biosphere, which should be coupled with Nature in any such 'Universal Declaration' as that intimated above.

Roger de Candolle
41 Chemin du Vallon
Chêne-Bougeries
1224 Geneva
Switzerland.

Roger de Candolle Chêne-Bougeries Switzerland.

\section{The Conservation Foundation}

Having ourselves suffered the-long-drawn-out agonies of seeking funds for worthy purposes of our own Foundation for Environmental Conservation in these most difficult times, we were particularly pleased to learn very recently, from the ever-informative monthly journal ENDS (Environmental Data Services Ltd, Orchard House, 14 Great Smith Street, London SW1P 3BU, England, UKsee ENDS Report 86, March 1982, page 16), of the launching of the above on 4 March at the Institute of $\mathrm{Di}$ rectors, London, to 'act as a broker between conservation projects needing funding and potential industrial sponsors'.

ENDS goes on to explain that 'The Foundation is a company limited by guarantee, and has charitable status. Its stated objectives are to encourage industry to support conservation; to organise and present annual Conserva- tion Awards, acknowledging both the conservation body and the sponsoring company; to create a central register of conservation projects which can be matched to the needs or interests of potential sponsors; and to establish through its membership a forum representing the various interests in industry and conservation'.

Further information about the above may be obtained from David Shreeve, The Conservation Foundation, Aviation House, 129 Kingsway, London WC2B 6NH, England, UK (telephone 01-242 4637 or 01-405 9736), whom we telephoned on learning of this admirable initiative, and who assured us that it will be widely international in its interests and objectives. Accordingly we welcome it most warmly as an innovation that seems destined to fill a long-felt need, and wish it the greatest possible success.

\section{Near-completion of Our Panel of Advisory Editors}

In planning this Journal nearly ten years ago, provision was made mentally (and subsequently established contractually) for a panel (not 'board', as it does not actually meet to confer) of Advisory Editors that should not exceed fifty in number. They are distinguished individuals who are commonly leaders in their specialist field of endeavour and/or organizational allegiance, and at our last reporting (Environmental Conservation, Vol. 8, No. 2, p. 90, Summer 1981) numbered forty-six, with three vacancies and one in reserve. Between them they cover, so far as can be foreseen and maintained, the whole vast range of scientific and other subjects comprising the main theme of our Journal and also due representation of its chief collaborating organizations. Vacancies on the panel are normally filled by invitation after confidential consultation, so unsolicited applications are unlikely to be successful.

We are now happy to announce the acceptance of our invitation to occupy our 'chair' of Ecosystems Research by Professor Eugene P. Odum, Director of the Institute of Ecology, University of Georgia, Athens, Georgia 30601 , USA, on completion of the latest revision of his rightly-famed Fundamentals of Ecology, and of that renamed Human Behaviour by Dr Ivan Polunin on his retirement from the National University of Singapore. Apart from the single reserve, this leaves only the theme listed as 'Evolutionary Ecology' to be covered-correspondence concerning which, and allied matters, indicate that our 'chairs' are widely coveted.

To our dismay, David Hughes-Evans has resigned as Executive Officer of our collaborators the World Environment and Resources Council (WERC), and so cannot continue as their representative on our panel. This has also been a factor in the return to us temporarily of responsibility for the World Decade of The Biosphere-until we can secure its adoption by a really 